\title{
KINETIC SPECTROPHOTOMETRIC METHOD FOR THE QUANTITATIVE ANALYSIS OF STREPTOMYCIN SULFATE
}

\author{
MASOOM RAZA SIDDIQUI ${ }^{*}$, SAIKH MOHAMMAD WABAIDUR ${ }^{a}$, ZEID A. AL OTHMAN ${ }^{a}$, \\ MD. SAJID ALI ${ }^{b}$, MD. SARFARAZ ALAM \\ ${ }^{a}$ Advanced materials research chair, Chemisty Department, College of Science, King Saud University, Riyadh-11451. Saudi Arabia \\ ${ }^{b}$ College of pharmacy, Jazan University, Jazan. Saudi Arabia.
}

\begin{abstract}
Kinetic method has been developed for the quantitative analysis of streptomycin. The method is based on the oxidation of the drug with the mixture of potassium iodide and potassium iodate to form a yellow colored product. Two methods are adopted for the determination process, the initial rate method and fixed time, absorbance difference method. Both the method followed Beer's law in the range of $4 \mu \mathrm{g} \mathrm{ml}^{-1}-72 \mu \mathrm{g} \mathrm{ml}{ }^{-1}$. The linear regression equation of initial rate and fixed time (absorbance difference) method was evaluated to be Rate $(\mathrm{U})=-1.026 \times 10^{-6}+5.93 \times 10^{-4} \mathrm{C}$ and $\Delta \mathrm{A}=-1.63 \times 10^{-3}+8.0 \times 10^{-3} \mathrm{C}$. The limit of detection of initial rate method and fixed time method was obtained to be 0.011 and 0.50 , respectively while limit of quantitation upon calculation came out to be 0.032 and 1.5 for initial rate and fixed time absorbance difference methods, respectively. Another important study in the proposed method is the activation parameter study which was done at four different temperatures i.e $298 \mathrm{~K}, 303 \mathrm{~K}, 308 \mathrm{~K}$ and $313 \mathrm{~K}$. Using the elevated temperature various activation parameters such as change in enthalpy $(\Delta \mathrm{H})$, change in entropy $(\Delta \mathrm{S})$ and Gibbs free energy $(\Delta \mathrm{G})$ was calculated and obtained to be $-34.41 \mathrm{~kJ} \mathrm{~mol}^{-1},-143.16$ and $-77.059 \times 10^{3} \mathrm{~kJ}$, respectively. Probable mechanism of the reaction has been mentioned in the text.
\end{abstract}

Keywords: Streptomycin, Absorbance, Activation parameters, Potassium iodate, Potassium iodide

\section{INTRODUCTION}

Streptomycin is an antibiotics belonging to group called aminoglycosides. Chemically it is known as bis[ $\left[N, N^{\prime}\right.$-bis(aminoiminomethyl)-4- $O$-[5-deoxy2-O-[2-deoxy-2-(methylamino)- $\alpha$-L-glucopyranosyl]-3-C-formyl- $\alpha$-Llyxofuranosyl]-D-streptamine] trisulphate. It is water soluble bactericidal antibiotics which act by interfering with the normal protein synthesis. The interference may be due to initiation, elongation and termination of protein synthesis. It is widely used antibiotics which can be used in the treatment of humans, veterinary as well as in the agriculture plants. Although, in human streptomycin alone is employed as a second line therapeutics against the tuberculosis, yet in recent years its important is growing because of its use in combination with other drugs for the treatment in tuberculosis. It is bactericidal to both the gram positive and gram negative strains of bacteria. Streptomycin is administered by regular intramuscular injections and is first effective medication for tuberculosis ${ }^{1}$. Despite of its serious nephrotoxicity and ototoxicity it remains the highly favored choice for the treatment of brucellosis and tularemia ${ }^{2}$. Several methods have been reported for the analysis of streptomycin sulfate, they include spectrophotometry ${ }^{3-7}$, HPLC $^{8,9}$. Other methods including Capillary zone electrophoresis ${ }^{10}$ and batch foam separation ${ }^{11}$, Spectrofluorimetry ${ }^{12}$ have been applied for estimating the content of streptomycin. To the best of our knowledge kinetic method based on increase in absorbance is still lacking in the literature. The low cost of the spectrophotometer make this technique easily available technique for the researchers and academics.

This paper describes the development and validation of kinetic spectrophotometric methods for the estimation of streptomycin sulfate in pharmaceutical formulations. The basis of the measurement is oxidation of streptomycin with potassium iodate which forms a carboxylic acid derivative. In the presence of - $\mathrm{COOH}$ group of the derivative the iodide is oxidized by iodate to form triiodide ion, which have a $\lambda_{\max }$ of $353 \mathrm{~nm}$. The increase in absorbance was observed therefore, initial rate and fixed time methods are applied to determine the content of streptomycin in commercial products. Further the activation parameter were studied and $\Delta \mathrm{H}^{\ddagger}, \quad \Delta \mathrm{S}^{\ddagger}$ and $\Delta \mathrm{G}$ were calculated.

\section{EXPERIMENTAL}

Apparatus

The absorbance of the samples was measured on Lambda 650 double beams UV/Vis spectrophotometer provided with multiple cell holders. The temperature of the cell was kept constant (at the desirable temperature) by circulating water using multi temperature of the same spectrophotometer.
Reagents and standards

Streptomycin sulfate was purchased from Fluka BioChemika (Fluka chemie, AG CH-9470 Buchs). Standard drug solution $\left(0.8 \mathrm{mg} \mathrm{m}^{-1}\right)$ was prepared by dissolving $40 \mathrm{mg}$ of streptomycin sulfate in $50 \mathrm{ml}$ of Milli Q water. The same solution was used to prepare the linearity samples and quality control samples which were prepared at three concentration levels of 4, 32 and $64 \mu \mathrm{g}$ $\mathrm{ml}^{-1}$. Marketed products applied for the recovery experiments are Ambistryn $\mathrm{S}(1000 \mathrm{mg})$ and Cipstryn $(1000 \mathrm{mg})$, the formulations were purchased from the Indian market.

Potassium iodide (KI) was obtained from BDH chemie, Poole, England. $0.07 \mathrm{~mol} / 1 \mathrm{KI}$ was used in the determination experiments, and should be prepared freshly in Milli $\mathrm{Q}$ water. $0.005 \mathrm{~mol} / 1$ potassium iodate solution used in the method development process was also freshly prepared and was purchased from the same company as that of Potassium iodide.

Recommended procedure for the determination of Streptomycin

Initial rate method:

Different volumes of $0.8 \mathrm{mg} \mathrm{ml}^{-1}$ streptomycin ranging from $0.05 \mathrm{ml}$ to $0.9 \mathrm{ml}$ were pipetted into a series of $10 \mathrm{ml}$ standard flask. To each flask $2 \mathrm{ml}$ each of $0.07 \mathrm{~mol} / 1 \mathrm{KI}$ and $0.005 \mathrm{~mol} / 1 \mathrm{KIO}_{3}$ were added in the same sequence and diluted up to the mark with Milli Q water. The content of the flask were well mixed and increase in absorbance with increase in time was recorded at $353 \mathrm{~nm}$. At varied concentration of drug, initial rate of reaction was achieved by determining the slope of the tangent to the absorbance-time graph. The plot of initial rate of reaction verses the molar concentration of streptomycin yielded the amount of drug. The amount of drug can also be computed from the regression equation of the plot.

Fixed time, absorbance difference $(\Delta \mathbf{A})$ method:

In this method of analysis, the absorbance of samples at the selected concentrations was measured at $353 \mathrm{~nm}$ against the reagent blank. The difference between the absorbance found at 2 minute and that obtained at 4 , $6,8,10$ or 12 min was plotted against the concentration of streptomycin sulfate to get the calibration graph. The amount of drug can be calculated from the calibration graph or the linear regression equation.

Determination of streptomycin in commercial dosage forms.

Ambistryn S and Cipstryn, each vial containing $1000 \mathrm{mg}$ were reconstituted in $10 \mathrm{ml}$ Milli Q water, further $0.8 \mathrm{ml}$ of the reconstituted solution was dissolved in $100 \mathrm{ml}$ water to prepare a test solution of $0.8 \mathrm{mg} \mathrm{ml}^{-1}$.

\section{RESULT AND DISCUSSION}

Spectral studies

During the spectral comparison of the pure streptomycin, reagent blank 
and the oxidation product it was observed that maximum absorbance of the streptomycin sulfate was at $237 \mathrm{~nm}$ while the blank solution which is the mixture of iodide and iodate absorbs maximally at $270 \mathrm{~nm}$ and $290 \mathrm{~nm}$. Upon the addition of the drug to the reagent blank the reactions starts and a shift in absorption band is observed which is credited to the oxidation of streptomycin sulfate by the potassium iodate. The new band for the reaction product appeared at $353 \mathrm{~nm}$ (Figure1). The equilibrium of the reaction appears after 30 minutes thus this condition was exploited to determine the streptomycin content kinetically.

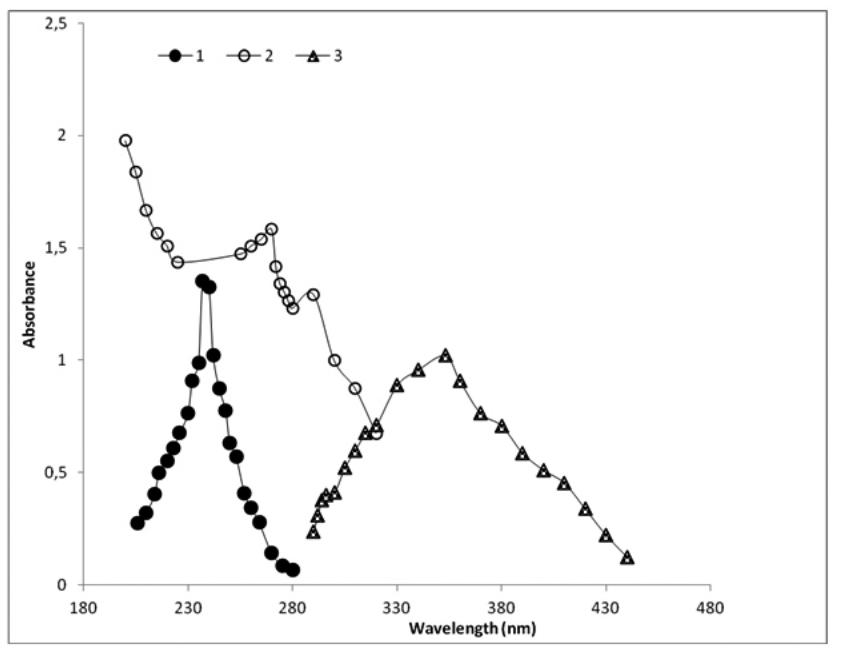

Figure 1: Absorption spectra of (1) $1.09 \times 10^{-6} \mathrm{~mol} / 1$ streptomycin in Milli Q water (2) $7.0 \times 10^{-3} \mathrm{M} \mathrm{KIO}_{3}+5.0 \times 10^{-4} \mathrm{~mol} / 1 \mathrm{KI}$ (3) $4.94 \times 10^{-5} \mathrm{M}$ Streptomycin $+1.0 \times 10^{-3} \mathrm{~mol} / 1 \mathrm{KIO}_{3}+1.4 \times 10^{-2} \mathrm{~mol} / 1 \mathrm{KI}$.

\section{Mechanism of the reaction}

Rahman et al. ${ }^{13}$ reported that the methyl group undergoes oxidation with iodate to form a carboxylic acid derivative. In the current study, the reaction proceeds in the similar fashion where streptomycin having methyl group undergoes oxidation with iodate. In presence of the carboxylic acid derivative of streptomycin iodate again oxidizes the iodide in the reaction forming a triiodide ion. The reaction sequence is shown in scheme 1.
A)

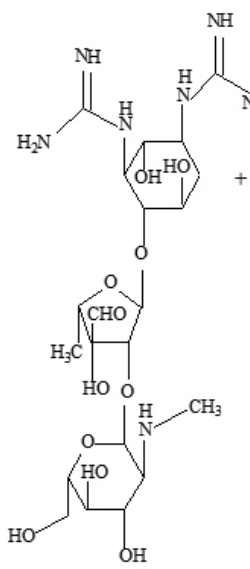<smiles>C1CCCCC1</smiles><smiles>[I-]</smiles>

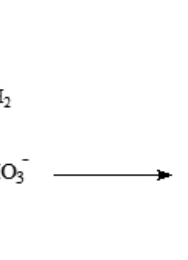

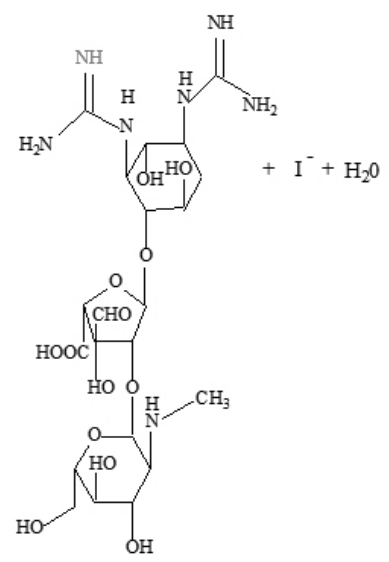

B)

$$
6 \mathrm{H}^{+}+\mathrm{IO}_{3}^{-}+5 \mathrm{I}^{-} \longrightarrow \begin{aligned}
& \text { triodide ion } \\
& \text { (colored species) }
\end{aligned} 2 \mathrm{I}_{3}^{-}+3 \mathrm{H}_{2} \mathrm{O}
$$

Scheme 1: Probable reaction mechanism for the proposed method.

Optimization of variables

The optimum condition for the current proposed methods responsible for the formation of the yellow colored oxidation product were intensely studied and maintained throughout the experiment.

Effect of $\mathrm{KIO}_{3}$ : The role of $\mathrm{KIO}_{3}$ in the determination of streptomycin was studied and was observed that similar to that of the KI the initial rate increased with increasing concentration of $\mathrm{KIO}_{3}$. The increase in initial rate was observed upto the $8.5 \times 10^{-4} \mathrm{~mol} / 1 \mathrm{KIO}_{3}$ and remained constant upto 1.1 $\times 10^{-3} \mathrm{~mol} / \mathrm{l}$. Thus $1.0 \times 10^{-3} \mathrm{~mol} / 1$ was selected as an optimum in the current determination process.

Effect of KI: Influence of the concentration of $\mathrm{KIO}_{3}$ on the initial rate of reaction was investigated in the concentration range of $7.0 \times 10^{-3} \mathrm{~mol} / 1-1.54$ $\times 10^{-2} \mathrm{~mol} / \mathrm{l}$. The initial rate of the reaction increased with the increase in the concentration of $\mathrm{KI}$ and become constant at $1.26 \times 10^{-2} \mathrm{~mol} / \mathrm{l}$ and remained as such upto $1.54 \times 10^{-2} \mathrm{~mol} / \mathrm{l}$. Thus, $1.54 \times 10^{-2} \mathrm{~mol} / 1$ was selected as optimum value for the determination process.

\section{Effect of temperature}

The influence of temperature on the initial rate of reaction was examined at $298 \mathrm{~K}, 303 \mathrm{~K}, 305 \mathrm{~K}$ and $313 \mathrm{~K}$. The absorbance-time plot at these temperatures specifies the dependence of the initial rate on temperature. The initial rate at different concentrations of streptomycin at each mentioned temperatures was calculated and used for plotting the calibration plot. The highest linearity was obtained at $298 \mathrm{~K}$ which was finally selected for the determination process. Further the activation parameters were calculated using the elevated temperatures.

Analytical data and method validation

Initial Rate method

Under the investigational situations the higher concentrations of $\mathrm{KI}$ and $\mathrm{KIO}_{3}$ are employed, which establish a pseudo-order reaction, condition with respect to the reagent concentration. On the basis of the experimental interpretations, kinetic equation for the reaction may be written as:

Rate $=k[\mathrm{C}]^{n}\left[\mathrm{KIO}_{3}\right]^{m}[\mathrm{KI}]^{l}$

for $\left[\mathrm{KIO}_{3}\right] \geq 1.0 \times 10^{-3} \mathrm{~mol} / \mathrm{l}$ and $[\mathrm{KI}] \geq 1.54 \times 10^{-2} \mathrm{~mol} / 1$ at $298 \mathrm{~K}$

The above equation can be reduced to

rate $=k_{r}[\mathrm{C}]^{n}$

where, $k_{\dagger}, \mathrm{C}$ and $n$ are pseudo-order rate constant and concentration of streptomycin order of reaction, respectively. In the logarithmic form the equation can be written as:

$\log ($ rate $)=\log k_{\dot{\dagger}}+n \log \mathrm{C}$

The initial rates of reaction at varied concentration of streptomycin were evaluated by getting the slopes of the initial tangent, to the absorbance - time curve during first $12 \mathrm{~min}$ of the reaction (figure 2). The results are summarized in table 1 .

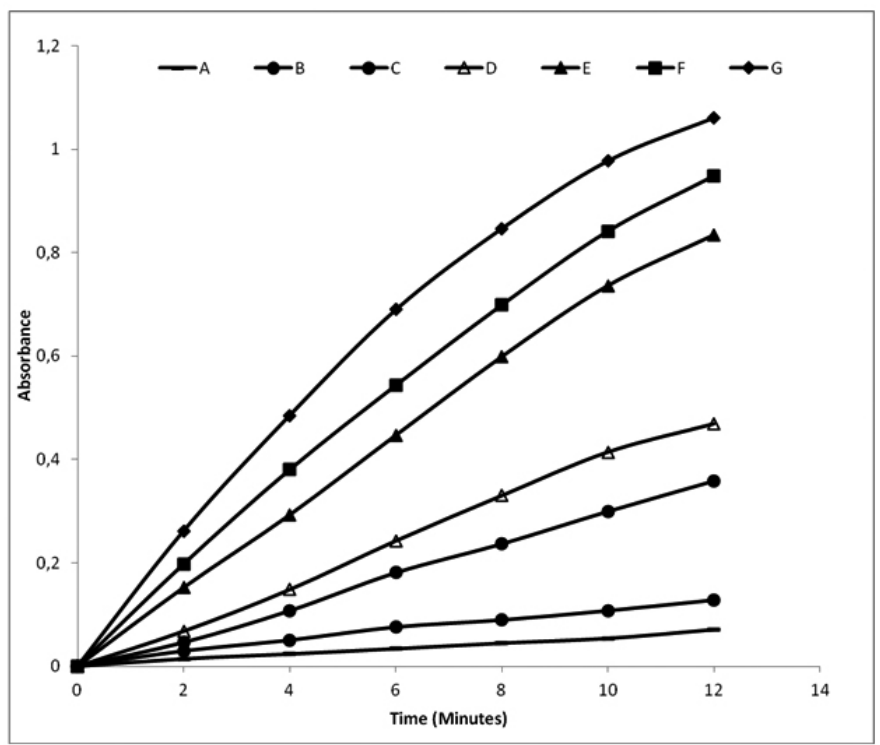

Figure 2: Absorbance-time graph of oxidation of streptomycin with mixture of potassium iodate and potassium iodide. $1.03 \times 10^{-3} \mathrm{~mol} / 1 \mathrm{KIO}_{3}$, $1.4 \times 10^{-2} \mathrm{~mol} / 1 \mathrm{KI}$ and (A) $2.74 \times 10^{-6}$ (B) $5.49 \times 10^{-6}$ (C) $1.65 \times 10^{-6}$ (D) $2.20 \times$ $10^{-6}(\mathrm{E}) 3.84 \times 10^{-6}(\mathrm{~F}) 4.39 \times 10^{-6}(\mathrm{G}) 4.94 \times 10^{-6} \mathrm{~mol} / 1$ streptomycin 
Table 1. Initial rate of reaction at different concentration of streptomycin keeping $\left[\mathrm{KIO}_{3}\right]$ and $[\mathrm{KI}]$ constant

\begin{tabular}{|c|c|c|c|}
\hline $\mathrm{C},[$ Drug] moll- & $\log \mathrm{C}$ & $\begin{array}{c}\text { Initial rate of reaction } \\
(\mathrm{U}) \mathrm{mol} \mathrm{L}^{-1} \mathrm{~S}^{-1}\end{array}$ & $\log \mathrm{U}$ \\
\hline $2.7445 \times 10^{-6}$ & -5.5615 & 0.0057 & -2.2436 \\
\hline $1.6467 \times 10^{-6}$ & -5.2604 & 0.0082 & -2.0861 \\
\hline $2.1956 \times 10^{-5}$ & -4.7833 & 0.0030 & -1.5217 \\
\hline $2.1956 \times 10^{-5}$ & -4.6584 & 0.0416 & -1.3810 \\
\hline $3.8425 \times 10^{-5}$ & -4.4153 & 0.0734 & -1.1343 \\
\hline $4.3913 \times 10^{-5}$ & -4.3574 & 0.0824 & -1.0837 \\
\hline $4.9402 \times 10^{-5}$ & -4.3062 & 0.0852 & -1.0693 \\
\hline
\end{tabular}

The graph of $\log$ rate versus $\log \mathrm{C}$ produced following linear equation $\log ($ rate $)=3.262+1.0004 \log \mathrm{C}$

The correlation coefficient of the regression equation came out to be 0.9913. The value of $\mathrm{n}$ in the equation approves that the reaction is first order with respect to streptomycin.

Further a graph of initial rate of reaction versus the initial concentration of streptomycin was plotted and was found that the drug gave a linear response in the concentration range of $4 \mu \mathrm{g}-72 \mu \mathrm{g}$. The statistical treatment of the data using the least square method was used to evaluate the slope intercept and the correlation coefficient. The graph of rate versus the concentration produced the following linear regression equation.

Rate $=-1.026 \times 10^{-6}+5.93 \times 10^{-4} \mathrm{C}$.

The correlation coefficient came out to be 0.9957 . The limit of detection and quantitation was calculated to be 0.011 and 0.032 , respectively while the variance of the calibration line was calculated to be $3.53 \times 10^{-12}$. Such a low value of the variance show negligible scattering of investigational figures around the line of regression. The assessment of the confidence limits of slope $\left(b \pm t S_{b}\right)$ and confidence limit of intercept $\left(a \pm t S_{b}\right)$ was performed and their value was computed and came out to be $5.93 \times 10^{-4} \pm 1.30 \times 10^{-6}$ and $-1.026 \times 10^{-6}$ $\pm 2.54 \times 10^{-5}$, respectively. The appreciably low value of the confidence limit indicates high reproducibility of the initial rate method

Fixed time method, Absorbance difference $(\Delta \mathrm{A})$ method:

In this method of analysis the absorbance of the reaction product is recorded for the first 12 minutes of the reaction at an interval of $2 \mathrm{~min}$. The difference in absorbance between $T_{I}(2 \mathrm{~min})$ and $\mathrm{T}_{2}(4,6,8,10$ or 12 minutes) was calculated and plotted against the concentration of streptomycin. The details of the linear regression equations are given in table 2. From the table it is clear that highest linearity was obtained with the difference between 2 and 8 minutes. Therefore, this fixed time was recommended for the analysis of streptomycin. The calibration plot was found to be linear in the concentration range of $4-72 \mu \mathrm{g} \mathrm{ml}^{-1}$ of streptomycin. The limit of detection (LOD), Limit of quantitation (LOQ) and variance was found to be $0.495,1.5$ and $1.44 \times 10$ ${ }^{4}$. The linear regression equation corresponding to the fixed time, absorbance difference method came out to be $-1.63 \times 10^{-3}+8.0 \times 10^{-3} \mathrm{C}$.

Table 2: Details of the linear regression equation at $\mathrm{A}_{4}-\mathrm{A}_{2}, \mathrm{~A}_{6}-\mathrm{A}_{2}, \mathrm{~A}_{8}-\mathrm{A}_{2}$ $\mathrm{A}_{10}-\mathrm{A}_{2,} \mathrm{~A}_{12}-\mathrm{A}_{2}$.

\begin{tabular}{|c|c|c|c|c|c|}
\hline$\Delta \mathrm{A}$ & $\begin{array}{c}\text { Calibration } \\
\text { Equation }\end{array}$ & $\mathrm{r}$ & $\mathrm{SD}$ & $\pm \mathrm{tS}_{\mathrm{a}}$ & $\pm \mathrm{tS}_{\mathrm{b}}$ \\
\hline $\mathrm{A}_{4}-\mathrm{A}_{2}$ & $\begin{array}{c}-7.7 \times 10^{-3}+ \\
2.97 \times 10^{-3} \mathrm{C}\end{array}$ & 0.9909 & 0.0123 & 0.0081 & $1.81 \times 10^{-4}$ \\
\hline $\mathrm{A}_{6}-\mathrm{A}_{2}$ & $\begin{array}{c}-3.52 \times 10^{-3}+ \\
5.64 \times 10^{-3} \mathrm{C}\end{array}$ & 0.9959 & 0.0151 & 0.0102 & $2.27 \times 10^{-4}$ \\
\hline $\mathrm{A}_{8}-\mathrm{A}_{2}$ & $\begin{array}{c}-1.63 \times 10^{-3}+ \\
8.0 \times 10^{-3} \mathrm{C}\end{array}$ & 0.9995 & 0.0012 & 0.0049 & $1.08 \times 10^{-4}$ \\
\hline $\mathrm{A}_{10}-\mathrm{A}_{2}$ & $\begin{array}{c}7.66 \times 10^{-3}+ \\
1.0 \times 10^{-2} \mathrm{C}\end{array}$ & 0.9989 & 0.0038 & 0.0093 & $2.07 \times 10^{-4}$ \\
\hline $\mathrm{A}_{12}-\mathrm{A}_{2}$ & $\begin{array}{c}2.52 \times 10^{-2}+ \\
1.12 \times 10^{-2} \mathrm{C}\end{array}$ & 0.9973 & 0.0245 & 0.0165 & $3.69 \times 10^{-4}$ \\
\hline
\end{tabular}

*SD:- Standard Deviation

$\mathrm{tSa}$ and $\mathrm{tS}_{\mathrm{b}}$ are the standard deviations of intercept and slope, respectively
Activation parameters study of the proposed method.

The activation parameters were studied by studying the rate of reaction at $298,303,308$ and $313 \mathrm{~K}$ keeping the following reaction conditions.

$[$ Streptomycin $]=2.74 \times 10^{-6} \mathrm{~mol} / 1,\left[\mathrm{KIO}_{3}\right]=1.4 \times 10^{-2} \mathrm{~mol} / 1,[\mathrm{KI}]=1.0 \times 10^{-3}$ $\mathrm{mol} / \mathrm{l}$

The Eyrring plot of $\ln \mathrm{K}_{\text {obs }} / \mathrm{T}$ versus $1 / \mathrm{T}$ was prepared and correlation coefficient, $r$ was found to be 0.945 (Figure 3). The change in $\Delta \mathrm{H}^{*}$ and $\Delta \mathrm{S}^{\ddagger}$ $\Delta \mathbf{S}^{\ddagger}$ were calculated from the slope $\frac{\Delta \mathbf{H}^{\ddagger} \Delta \mathbf{H}^{\ddagger}}{R}$ and intercept $\left[\ln \frac{K_{B}}{\boldsymbol{h}} \frac{K_{B}}{\boldsymbol{h}}+\frac{\Delta \mathbf{S}^{\ddagger}}{R}\right.$ $\left.\frac{\Delta \mathrm{s}}{R}\right]$ of the Eyrring plot and the value was obtained to be $-34.41 \mathrm{~kJ} \mathrm{~mol}^{-1}$ and -143.16. Gibbs free energy was calculated using the equation. $\Delta \mathrm{G}=-\mathrm{RT} \ln \mathrm{K}$ and it was found to be $-77.059 \times 10^{3} \mathrm{~kJ}$. The negative value of $\Delta \mathrm{S}$ indicates that the activated complex is associated in nature and cause a decrease in entropy.

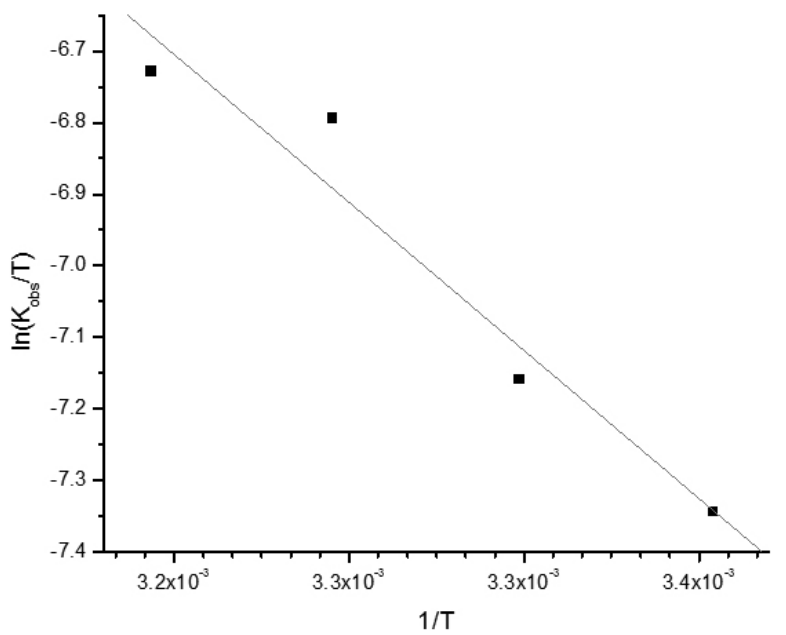

Figure 3: Eyring Plot of $\ln \mathrm{k}_{\mathrm{obs}} / \mathrm{T}$ versus $1 / \mathrm{T}$ at $298 \mathrm{k}, 303 \mathrm{k}, 308 \mathrm{~K}$ and $313 \mathrm{~K}$; Streptomycin $=2.74 \times 10^{-6} \mathrm{~mol} / 1 \mathrm{KIO}_{3}=1.03 \times 10^{-3} \mathrm{~mol} / 1, \mathrm{KI}=1.4 \times 10^{-2}$ $\mathrm{mol} / \mathrm{l}$.

\section{Accuracy and precision of the proposed method}

To establish the accuracy and precision of the proposed method interday and intraday assay was performed. By the interday and intraday assay, the content of streptomycin was determined in quality control samples at three different concentration levels of $4 \mu \mathrm{g} \mathrm{ml}^{-1}, 32 \mu \mathrm{g} \mathrm{ml}^{-1}$ and $64 \mu \mathrm{g} \mathrm{ml}^{-1}$ by performing five independent analyses. Intraday assay was performed within 1day while the interday assay was performed for 5 days. Results are summarized in table 3 . Statistical treatment of the data yielded standard deviation, relative standard deviation and standard analytical error. For both the methods these parameters are acceptable as is within the permissible bias range. Thus the accuracy and precision results can be considered satisfactory.

\section{Validity of the proposed method}

To evaluate the validity of the proposed method, standard addition method was employed. In this method a known quantity of pure streptomycin was added to its formulated forms at three different concentration levels. The nominal value of streptomycin was computed using the proposed methods. The results in Table 4 show that the recoveries obtained by both the procedures are very satisfactory.

Robustness

In the analytical procedure robustness refers to the ability of the method to remain unaffected by deliberate but small variations in the method parameters. In the current study robustness was ascertained by variation in the volume of $0.005 \mathrm{~mol} / 1 \mathrm{KIO}_{3}( \pm 4 \mathrm{ml}) 0.07 \mathrm{~mol} / 1 \mathrm{KI}( \pm 3 \mathrm{ml})$. Under the varied condition the quality control samples were analyzed at concentration level of 16 and $48 \mu \mathrm{g} \mathrm{ml}$ ${ }^{1}$. Results are acceptable with excellent recoveries.

\section{Solution stability}

The stability of the streptomycin sulfate solution was checked by recording the absorption spectra of the drug for 7 days. No change in the absorption spectra was observed during these days. Further the stability with respect to the assay of the streptomycin solution was checked by determining the content of streptomycin after storing it at room temperature $\left(25^{\circ} \mathrm{C} \pm 1^{\circ} \mathrm{C}\right)$ and at refrigerated condition $\left(2-8^{\circ} \mathrm{C}\right)$. Sample prepared were analyzed for its assay at $0-24$ hour with a gap of 6 hours. The result of the study was used to evaluate the $\%$ content change in streptomycin with respect to time zero. It was observed that total degradation after 24 hours at the room temperature condition was $1.45 \%$ while that of at refrigerated condition was $0.78 \%$. 
Table 3. Evaluation of accuracy and precision of the proposed method by intraday and interdat assay.

\begin{tabular}{|c|c|c|c|c|c|}
\hline \multirow{2}{*}{ Proposed Methods } & \multicolumn{2}{|c|}{ Amount $\mu \mathrm{g} \mathrm{ml}^{-1}$} & \multirow{2}{*}{$\operatorname{RSD}(\%)$} & \multirow{2}{*}{$\mathrm{SAE}^{\mathrm{b})}$} & \multirow{2}{*}{ C. $L^{c)}$} \\
\hline & Taken & Found $\pm \mathrm{SD}^{\mathrm{a})}$ & & & \\
\hline \multicolumn{6}{|l|}{ Initial Rate } \\
\hline \multirow[t]{3}{*}{ Intra Day Assay } & 4 & $3.98 \pm 0.048$ & 1.18 & 0.021 & 0.059 \\
\hline & 32 & $31.96 \pm 0.286$ & 0.89 & 0.128 & 0.356 \\
\hline & 64 & $64.06 \pm 0.765$ & 1.19 & 0.324 & 0.949 \\
\hline \multirow[t]{3}{*}{ Interday Assay } & 4 & $3.98 \pm 0.068$ & 1.17 & 0.030 & 0.084 \\
\hline & 32 & $32.20 \pm 0.515$ & 1.59 & 0.23 & 0.639 \\
\hline & 64 & $64.09 \pm 0.855$ & 1.33 & 0.382 & 1.06 \\
\hline \multicolumn{6}{|c|}{ Fixed Time $(\Delta \mathbf{A})$ method } \\
\hline \multirow[t]{3}{*}{ Intra Day Assay } & 4 & $4.00 \pm 0.058$ & 1.43 & 0.026 & 0.071 \\
\hline & 32 & $31.80 \pm 0.052$ & 1.62 & 0.231 & 0.043 \\
\hline & 64 & $64.01 \pm 0.886$ & 1.38 & 0.396 & 1.099 \\
\hline \multirow[t]{3}{*}{ Interday Assay } & 4 & $4.00 \pm 0.054$ & 1.35 & 0.024 & 0.025 \\
\hline & 32 & $32.01 \pm 0.564$ & 1.76 & 0.252 & 0.700 \\
\hline & 64 & $64.05 \pm 0.971$ & 1.51 & 0.434 & 1.20 \\
\hline
\end{tabular}

Table 4. Standard addition method for the determination of streptomycin in commercial dosage form.

\begin{tabular}{|c|c|c|c|c|c|c|c|c|c|c|c|c|}
\hline \multirow[t]{2}{*}{ Formulations } & \multicolumn{3}{|c|}{$\begin{array}{l}\text { Initial rate method } \\
\text { Amount }\left(\mu \mathrm{g} \mathrm{ml}^{-1}\right)\end{array}$} & \multirow[b]{2}{*}{$\begin{array}{c}\text { Recovery } \\
(\%)\end{array}$} & \multirow[b]{2}{*}{$\begin{array}{l}\text { RSD } \\
(\%)\end{array}$} & \multirow[b]{2}{*}{ SAE } & \multicolumn{3}{|c|}{ Fixed time $(\Delta \mathrm{A})$ method } & \multirow[b]{2}{*}{$\begin{array}{l}\text { Recovery } \\
(\%)\end{array}$} & \multirow[b]{2}{*}{$\begin{array}{l}\text { RSD } \\
(\%)\end{array}$} & \multirow[b]{2}{*}{ SAE } \\
\hline & Taken & Added & Found \pm SD & & & & Taken & Added & Found \pm SD & & & \\
\hline & 8 & 8 & $16.04 \pm 0.19$ & 100.28 & 1.17 & 0.08 & 8 & 8 & $16.09 \pm 0.25$ & 100.53 & 1.58 & 0.11 \\
\hline & 8 & 32 & $40.07 \pm 0.19$ & 100.17 & 0.63 & 0.11 & 8 & 32 & $40.15 \pm 0.73$ & 100.38 & 1.81 & 0.33 \\
\hline & 8 & 32 & $40.03 \pm 0.37$ & 100.09 & 0.93 & 0.17 & 8 & 32 & $40.09 \pm 0.47$ & 100.22 & 1.18 & 0.21 \\
\hline & 8 & 56 & $63.91 \pm 0.61$ & 99.86 & 0.96 & 0.27 & 8 & 56 & $64.14 \pm 0.63$ & 100.22 & 0.98 & 0.28 \\
\hline
\end{tabular}

Table 5: Point and interval hypothesis tests: Comparison of the proposed method with the reference method.

\begin{tabular}{|c|c|c|c|c|c|c|c|c|c|c|c|c|c|c|}
\hline \multirow{3}{*}{ Formulation } & \multicolumn{6}{|c|}{ Point hypothesis test } & \multicolumn{8}{|c|}{ Interval hypothesis test } \\
\hline & \multicolumn{2}{|c|}{$\begin{array}{l}\text { Initial rate } \\
\text { method }\end{array}$} & \multicolumn{2}{|c|}{$\begin{array}{l}\text { Fixed time } \\
(\Delta \mathrm{A}) \text { method }\end{array}$} & \multicolumn{2}{|c|}{ Reference method } & \multicolumn{4}{|c|}{ Initial rate method } & \multicolumn{4}{|c|}{ Fixed time method } \\
\hline & recovery & $\begin{array}{l}\mathrm{RSD}^{\mathrm{a})} \\
(\%)\end{array}$ & recovery & $\begin{array}{c}\mathrm{RSD}^{\mathrm{a}} \\
(\%)\end{array}$ & recovery & $\begin{array}{l}\mathrm{RSD}^{\mathrm{a})} \\
(\%)\end{array}$ & $\begin{array}{c}\mathrm{t}- \\
\text { value }\end{array}$ & $\begin{array}{c}\mathrm{F}- \\
\text { value }\end{array}$ & $\theta_{\mathrm{L}}$ & $\theta_{\mathrm{U}}$ & $\begin{array}{c}\mathrm{t}- \\
\text { value }\end{array}$ & $\begin{array}{c}\text { F- } \\
\text { value }\end{array}$ & $\theta_{\mathrm{L}}$ & $\theta_{\mathrm{U}}$ \\
\hline Cipstryn & 100.13 & 0.80 & 100.25 & 1.15 & 100.10 & 0.87 & 0.554 & 0.467 & 0.999 & 1.001 & 1.058 & 0.130 & 0.999 & 1.003 \\
\hline
\end{tabular}

Limit of detection (LOD) and limit of quantitation (LOQ)

As per the guidelines of the international conference on harmonization $(\mathrm{ICH})^{14}$. LOD and LOQ can be evaluated using the following equations.

LOD $=3.3 \times \frac{S_{0}}{b}$ and LOQ $=10 \times \frac{S_{0}}{b} \quad$ where $S_{0}$ and b are standard deviation and slope of the calibration line. The LOD of the initial rate method and fixed time was found to be 0.011 and 0.50 while LOQ of the two methods came out to be 0.032 and 1.5 , respectively.

Applicability of the proposed method and evaluation of bias.

Applicability of the initial rate and the absorbance difference $(\Delta \mathrm{A})$ method was used to calculate the assay of streptomycin in the marketed formulations.
The results of the proposed methods were statistically compared with those of the reference method (reported method from the literature) using the point and interval hypothesis ${ }^{15,16}$. In the interval hypothesis the offered method is accepted when the true mean is within the range of $\pm 2 \%$ of that of the reference method i.e.

$-0.02 \mu_{1}<\left(\mu_{2}-\mu_{1}\right)<0.02 \mu_{1}$

The overhead equation can also be written as:

$0.98<\mu_{2} / \mu_{1}<1.02$

Which, can be generalized to

$\theta_{\mathrm{L}}<\mu_{2} / \mu_{1}<\theta$ 
Where, $\theta_{\mathrm{L}}$ and $\theta_{\mathrm{U}}$ are lower and upper acceptance limits, respectively. The limits of this confidence interval can be calculated as the two roots of the following quadratic equation.

$$
\theta^{2}\left(\overline{x_{1}^{2}}-S_{p}^{2} t_{t a b}^{2} / n_{1}\right)-2 \theta \overline{x_{1} x_{2}}+\theta^{2}\left(\overline{x_{2}^{2}}-S_{p}^{2} t_{t a b}^{2} / n_{2}\right)=0
$$

Where,

$$
\begin{gathered}
a=\overline{x_{1}^{2}}-\frac{S_{p}{ }^{2} t_{t a b}{ }^{2}}{n_{1}} \\
\mathrm{~b}=-2 \overline{x_{1} x_{2}} \\
c=\overline{x_{2}^{2}}-\frac{S_{p}{ }^{2} t_{t a b}{ }^{2}}{n_{2}}
\end{gathered}
$$

The values of $\theta_{\mathrm{L}}$ and $\theta_{\mathrm{U}}$ of the confidence interval can be obtained as:

$$
\begin{aligned}
& \theta_{L}=\frac{-b-\sqrt{b^{2}-4 a c}}{2 a} \\
& \theta_{u}=\frac{-b+\sqrt{b^{2}-4 a c}}{2 a}
\end{aligned}
$$

Results from table 5 shows there is no significant difference between the methods compared.

\section{CONCLUSION}

The proposed methods are a direct determination of streptomycin at $25^{\circ} \mathrm{C}$. The current method is free from any pretreatments. The methods are very rapid and can be completed within $10 \mathrm{~min}$. No interference from the excipients was observed during the assay process. Thus we can conclude that the proposed methods are suitable for the determination of streptomycin in pharmaceutical formulations. It can be used to routine analysis of streptomycin in quality control laboratories, laboratories of hospitals, pharmaceutical industries and academic research institutions.

\section{ACKNOWLEDGEMENTS}

The authors extend their appreciation to the Deanship of Scientific Research, College of Science Research Center, King Saud University, Riyadh, Saudi Arabia for supporting this project.

\section{REFERENCES}

1. E.C. Cox, J.R. White, J.G. Flaks, Proc. Natl. Acad. Sci. 51,703 (1964).

2. S. S. Mitic, S. M. Sunaric, and S.B. Tosic. Anal. Sci. 22, 753 (2006).

3. Y. Fujita, I. Mori, S. Kitano . Chem Pharm. Bull. 31,1289(1983).

4. A.M. Wahbi, H. Abdine, A. Rafik, H. Sadek. Pharmazie 32,690(1977).

5. S. S Mitic, S. M Sunaric, S. B Tosic Anal Sci. 22, 753(2006).

6. Q.-M. Li, L.-X. Gao, Anal. Lett. 41, 2595(2008).

7. T. Amaan, A. Rashid, R. Kulsoom, I. Khokhar, Anal. Lett. 28,881(1995).

8. O. Granados, G. Meza. J Pharm Biomed Anal. 43,625(2007).

9. Shafqat ullah, A. Hussain, Asad ullah, W. Hussain, Khaliq-ur-Rehman World Appl. Sci. J. 19,645(2012).

10. P.P. Maia, J. Amaya-Farf' an, S. Rath, F. G.Reyes. J. Pharm. Biomed. Anal. 43,450(2007)

11. B. Han, Z. Wu, H.Yin, T.Feng. Sep. Sci. and Technol. 45,844(2010).

12. F Belal, S.M El-Ashry, M.M El Kerdawy, D.R El Wasseef. J. Pharm Biomed Anal. 26, 435(2001)

13. N. Rahman, M.R. Siddiqui.S.N.H. Azmi. Chem Pham Bull. 54,626(2006).

14. International conference on Harmonisation, ICH Harmonised Tripartite
Guideline - Text on Validation of Analytical Procedures, Fed. Regist. $60,11260(1995)$

15. C. Hartmann, J. Smeyers-Verbeke, W. Penninckx, Y. V. Heyden, P. Vankeerberghen, D. L. Massart, Anal. Chem. 67,4491(1995).

16. Canada Health Protection Branch, Drugs Directorate guidelines, Acceptable methods, Ministry of National Health and Welfare, Draft, 1992. 